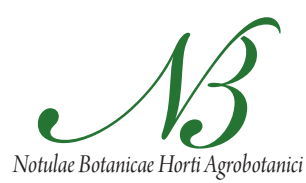

Cluj-Napoca

\title{
Breeding for Chlorogenic Acid Content in Eggplant: Interest and Prospects
}

\author{
Mariola PLAZAS, Isabel ANDÚJAR, Santiago VILANOVA, Maria HURTADO, \\ Pietro GRAMAZIO, Francisco J. HERRAIZ, Jaime PROHENS* \\ Instituto de Conservación y Mejora de la Agrodiversidad Valenciana, Universitat Politécnica de València, \\ Camino de Vera 14, 46022 Valencia, Spain; jprohens@btc.upv.es ("correspondingauthor)
}

\begin{abstract}
Chlorogenic acid (5-O-caffeoyl-quinic acid; CGA) is an ester of caffeic acid and (-)-quinic acid with many beneficial properties for human health, such as anti-oxidant, anti-inflammatory, cardioprotective, anti-carcinogenic, anti-obesity, and anti-diabetic properties. This has raised an interest for the development of new crop cultivars with increased CGA content. One of the crops with higher CGA content is eggplant (Solanum melongena). There is a wide diversity for CGA content in cultivated eggplant germplasm, which is influenced by the fruit developmental stage, storage conditions, and environmental factors. Therefore, appropriate experimental designs are required for an efficient breeding. Several strategies are proposed for breeding for high CGA content such as intraspecific variation, selection among accessions, development of hybrids and lines with good agronomic and commercial characteristics, or introgression of the high CGA trait in élite lines. Some wild relatives, like $S$. incanum, present higher CGA contents than those of eggplant. Interspecific hybridization can be used to introgress favorable alleles from the wild species into the genetic background of cultivated eggplant. Fruit flesh browning, as a result of CGA oxidation by polyphenol oxidases, could be a side effect of increasing the CGA content in eggplant. However, experimental results indicate that the relationship between CGA content and fruit flesh browning is low or moderate. Furthermore, selection for low polyphenol oxidase activity might result in reduced fruit flesh browning. Overall, the available data suggest that the development of eggplant cultivars with improved functional quality resulting from a higher CGA content is feasible.
\end{abstract}

Keywords: functional properties, germplasm, hybridization, polyphenol oxidase, Solanum incanum, Solanum melongena

\section{What is chlorogenic acid?}

Chlorogenic acid (5-O-caffeoyl-quinic acid; CGA) is a phenolic compound resulting from the esterification of caffeic acid and the aliphatic alcohol $(-)$ quinic acid $(1 \mathrm{~L}-$ $1(\mathrm{OH})-3,4 / 5$-tetrahydroxycyclo-hexane carboxylic acid) (Fig. 1). CGA is present in many plants where it plays a role in plant defense, as well as an antioxidant (Korkina, 2007; Leiss et al., 2009; Ngadze et al., 2012). The broader term "chlorogenic acids" has also been used to refer to a family of esters formed between certain trans-cinnamic acids (caffeic, ferulic and $p$-coumaric acids) and quinic acid (Clifford, 2000). The main subgroups of chlorogenic acids include: mono-esters of caffeic acid (caffeoylquinic acids, $p$-coumaroylquinic acids and feruloylquinic acids), di-esters, tri-esters, a single tetra-ester of caffeic acid, and mixed di-esters of caffeic and ferulic acid (caffeoylferuloylquinic acids) or caffeic and sinapic acid (caffeoylsinapoylquinic acids). Mixed esters involving various permutations of between one and three residues of caffeic acid with one or two residues of a dibasic aliphatic acid (such as glutaric, oxalic, succinic) have also been denominated chlorogenic acids (Clifford, 2000). However, for the purposes of the present paper we use the term chlorogenic acid (CGA) to refer specifically to 5-O-caffeoyl-quinic acid.
CGA is included in the broad category of polyphenols, which are typically classified into one of either two categories: flavonoids and phenolic acids (Macheix, 1990). Among the latter, hydroxycinnamic acids, of which CGA is a major representative, is considered the main class.

\section{The interest for breeding for CGA content: bioactive properties}

Dietary polyphenols from numerous plant species have shown to be beneficial for human health due to its known biological activities, which include free-radical scavenging, regulation of enzymatic activity, and modulation of several cell signaling pathways (Sato et al., 2011). In fact, many of them are being actively studied as potential treatments for various metabolic and cardiovascular diseases. For example, resveratrol from red wine, epigallocathechin3 -gallate from green tea, curcumin from turmeric, and quercetin from different sources have all been studied as potential therapeutic agents to induce weight loss, lower blood pressure, attenuate glucose levels and insulin resistance, and improve hemoglobin A1c and lipid profile in humans (Andújar et al., 2012).

CGA is found in many edible and medicinal plants, and is well known for having various biological properties 


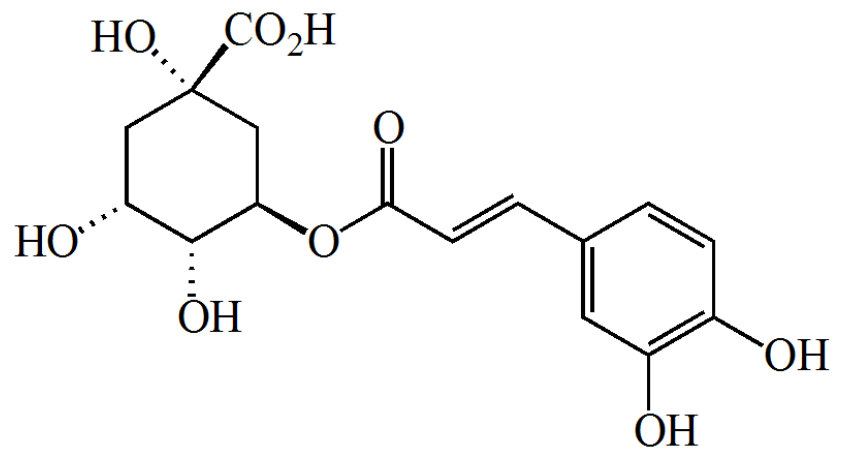

Fig. 1. Chemical structure of chlorogenic acid (5-O-caffeoylquinic acid; CGA)

of interest for human health. These include anti-oxidant, anti-inflammatory and analgesic properties demonstrated both in vitro and in vivo (dos Santos et al., 2006; Jin et al., 2006; Morishita and Ohnishi, 2001; Sato et al., 2011; Sheu et al., 2009), as well as strong anti-microbial activity (Almeida et al., 2006). In relation to this anti-oxidant/ anti-inflammatory activity, several studies also highlight CGA neuroprotective (Ahn et al., 2011) and cardioprotective (Chen et al., 2009; Zhao et al., 2012) effects.

A number of animal studies have indicated that CGA is hypotensive (Suzuki et al., 2002, 2006). This blood pressure-lowering activity also occurs in humans, as confirmed by clinical trials: the administration of $140 \mathrm{mg} /$ day of CGA to mildly hypertensive subjects decreased both systolic and diastolic blood pressure significantly (Watanabe et al., 2006).

CGA is also known to exert selective anti-carcinogenic effects via induction of apoptosis in many human cancer cells, such as leukemia cells (Yang et al., 2012) and lung cancer cells (Burgos-Morón et al., 2012). Other biological activities of CGA include its anti-obesity effect with improvement of lipid metabolism (Cho et al., 2010), and a delay in intestinal glucose absorption and inhibition of gluconeogenesis (Ong et al., 2012), which contributes to an anti-diabetic effect (Coman et al., 2012).

CGA is one of the most abundant polyphenols in the human diet and is highly bioavailable in nature (dos Santos et al., 2006). This fact, together with its numerous bioactive properties potentially beneficial for human health, encourages the use of breeding approaches in order to increase its level in food crops (Niggeweg et al., 2004).

\section{Eggplant as a source of CGA in the diet}

The major dietary sources of CGA are vegetables, fruits, and beverages like coffee (Azuma et al., 2000). It is estimated that humans consume up to $1 \mathrm{~g}$ of CGA per day (Chen et al., 2009). Although coffee is considered a major source of CGA in the human diet, as regular coffee drinkers may consume up to 0.5 - $1 \mathrm{~g}$ of CGA per day (Olthof et al., 2001), fruits and vegetables also make a substantial contribution to CGA intake (Olthof et al., 2001). In this respect, eggplant is one of the vegetables with a higher content in CGA (Tab. 1).

CGA is, by far, the major phenolic compound of the eggplant fruit, and typically makes between $80 \%$ and $95 \%$ of the total hydroxycinnamic acids present in the fruit flesh (Prohens et al., 2013; Stommel and Whitaker, 2003; Whitaker and Stommel, 2003). Also, it has been found that concentrations of CGA in the eggplant fruit skin are similar to those present in the fruit flesh (Gajewski $e t$ al., 2009). When compared with the estimation of the total phenolics content by means of the spectrophotometric method of Folin-Ciocalteu, CGA typically represents between $30 \%$ and $75 \%$ of the total phenolics of the fruit when harvested at the commercially mature stage (Luthria, 2012; Mennella et al., 2012). CGA content in eggplant flesh is highly correlated with total phenolics and antioxidant activity, with $\mathrm{r}^{2}$ values of 0.87 and $>0.95$, respectively (Luthria et al., 2010, 2012). These results confirm that CGA is the most relevant phenolic compound in the eggplant fruit, and the major contributor to the high antioxidant capacity of eggplant. In fact, eggplant ranks among the vegetables with highest oxygen radical absor-

Tab. 1. Comparison of contents in chlorogenic acid (5-O-caffeoyl-quinic acid; CGA) in eggplant with other major vegetables, fruits, and plant products providing significant amounts of CGA to the diet

\begin{tabular}{|c|c|c|}
\hline Plant source & $\begin{array}{c}\text { CGA } \\
\left(\mathrm{g} \cdot \mathrm{kg}^{-1} \mathrm{dw}\right)\end{array}$ & References \\
\hline \multirow{8}{*}{ Eggplant } & $4.9-21.6$ & Stommel and Whitaker (2003) \\
\hline & $4.2-9.5$ & Whitaker and Stommel (2003) \\
\hline & $1.5-2.2$ & Gajewski et al. (2009) \\
\hline & $5.0-8.1$ & Singh et al. (2009) \\
\hline & $2.6-6.7$ & Luthria et al. (2010) \\
\hline & $11.2-24.0$ & Mennella et al. (2010) \\
\hline & $1.4-8.4$ & Luthria (2012) \\
\hline & $14.1-28.0$ & Mennella et al. (2012) \\
\hline \multicolumn{3}{|c|}{ Other vegetables } \\
\hline Artichoke & $1.1-1.8$ & Lutz et al. (2008) \\
\hline Carrot & $0.3-18.8$ & Sun et al. (2009) \\
\hline Pepper & $0.7-0.9$ & $\begin{array}{c}\text { Hallmann and } \\
\text { Rembialkowska (2013) }\end{array}$ \\
\hline Tomato & $0.2-0.4$ & Hallmann (2012) \\
\hline \multicolumn{3}{|c|}{ Fruits } \\
\hline Apple & $0.4-1.2$ & van der Sluis et al. (2001) \\
\hline Apricot & $0.02-0.51$ & Madrau et al. (2009) \\
\hline Cherry & $0.02-0.09$ & Serra et al. (2011) \\
\hline Peach & $0.1-1.6$ & Andreotti et al. (2008) \\
\hline Plum & 0.4 & Khallouki et al. (2012) \\
\hline \multicolumn{3}{|c|}{ Other plant products } \\
\hline Coffee & $27.9-52.0$ & Monteiro and Farah (2012) \\
\hline Mate tea & $4.8-24.9$ & Heck et al. (2008) \\
\hline Potato & $0.01-4.60$ & Deußer et al. (2012) \\
\hline Sunflower seeds & $29.9-45.5$ & Singh et al. (1999) \\
\hline
\end{tabular}


28

bance capacity due to its high content in phenolics (Cao et al., 1996).

The multiple health benefits of eggplant, which include anti-oxidant, anti-diabetic, hypotensive, cardioprotective, and hepatoprotective effects (Akanitapichat et al., 2010; Das et al., 2011; Kwon et al., 2008), are largely attributed to its phenolic content, in particular to CGA. In addition, the content of CGA in eggplant increases after the thermal treatments normally used for eggplant cooking (Lo Scalzo et al., 2010). Also, it is worth mentioning that, although some phenolic compounds are bitter (Macheix, 1990), bitterness present in some cultivars of eggplant is caused by saponins and glycoalkaloids (Aubert et al., 1989; Sánchez-Mata et al., 2010) and not by CGA, which does not cause appreciable bitterness at the concentrations present in eggplant (Nagel et al., 1987). Therefore, breeding new cultivars of eggplant with enhanced CGA content is of interest, as these new cultivars would have a high added value derived from its improved nutraceutical properties without affecting its organoleptic properties.

\section{Variation for CGA content in eggplant}

Eggplant presents a wide morphological and molecular diversity (Hurtado et al., 2012; Prohens et al., 2005), as well as a broad variation for composition traits, including total phenolics and CGA content (Arivalagan et al., 2012; Hanson et al., 2006; Okmen et al., 2009; Prohens et al., 2007; Raigón et al., 2008; Stommel and Whitaker, 2003). Few studies have been performed in which the variation for CGA content has been studied in a relevant number of eggplant accessions. The first and broadest study was performed by Stommel and Whitaker (2003), who found differences of up to 4.4-fold in the CGA content and a continuous range of variation in a collection of 97 accessions of cultivated eggplant from the core collection of the USDA-ARS collection. These same authors also studied seven commercial varieties and found differences in CGA content of up to 2.2-fold among them (Whitaker and Stommel, 2003). Another study was performed by Mennella $e$ al. (2012), in which they studied the variation for CGA content in 10 accessions of eggplant at three ripening stages. These authors found differences of 2.8, 3.7, and 4.0-fold between accessions for the unripe, commercially mature, and physiologically ripe stages, respectively. Also, they found that the accessions of the non-Japanese type (containing the anthocyanin delphinidin-3-rutinoside in the fruit skin), on average, had a higher CGA content than the Japanese type (containing the anthocyanin nasunin in the fruit skin). However, a considerable diversity was found within each of these types (Mennella et al., 2012). Overall, the results of these studies show that there is a wide diversity for CGA content within cultivated eggplant germplasm.

There are a few more studies in which, although CGA has not been measured, the total phenolics content has been estimated. In this respect, Hanson et al. (2006) found differences of up to 1.7-fold for total phenolics in a study involving 35 accessions of eggplant, Prohens et al. (2007) of up to 3.0-fold in a collection of $69 \mathrm{~S}$. melongena accessions from different origins, Raigón et al. (2008) of up to 1.8fold in a collection of 31 commercial varieties, landraces, and experimental hybrids, and Okmen et al. (2009) of 2.2fold in a collection of 26 Turkish accessions of eggplant. A recent study, in which diversity for both CGA content and total phenolics were estimated (Mennella et al., 2012) shows that variation for total phenolics in a collection of 10 eggplant accessions is lower than variation for CGA content. In this respect, these authors found differences of 2.4, 2.0, and 2.2-fold between accessions for the unripe, commercially mature, and physiologically ripe stages, respectively, which are lower values for relative differences than those observed for CGA content (see above). These results confirm the wide variation for phenolic content, and therefore for CGA content, in eggplant.

Non-genetic sources of variation can also contribute to the wide range of variation observed for CGA content in eggplant. Mennella et al. (2012) found important differences among fruit developmental stages. These authors found that there is a sharp decrease in CGA content during the fruit development, so that average values in a collection of 10 eggplant cultivars for the unripe, commercially mature, and physiologically ripe stages were of 21.6, 12.9 , and $7.1 \mathrm{mg} \cdot \mathrm{kg}^{-1}$, respectively. Also, important differences, which are nutritionally relevant, have been found by Whitaker and Stommel (2003) among different parts of the eggplant fruit. These authors found that the fruit flesh from midsection and blossom end part of the fruit had much higher content in CGA (on average 93\% and $76 \%$ higher, respectively) than the stem end of the fruit. Also, Gajewski et al. (2009) found an average decrease of $37 \%$ in the CGA content after storage of eggplant for one week at $16^{\circ} \mathrm{C}$. Contrarily, Concellón et al. (2012) found that storage for 14 days at $10^{\circ} \mathrm{C}$ increased CGA content, while a reduction was observed when stored at $0^{\circ} \mathrm{C}$.

Not much information exists for variation among years or cultivation conditions for CGA in eggplant. Mennella et al. (2010) found small (5\%), although statistically significant, differences between two years for CGA content in eggplant genotypes; however, yearly differences were much higher (46\%) for eggplant lines with introgressions from S. aethiopicum L. Hanson et al. (2006) also found very large and significant differences in total phenolics with average differences of $50 \%$ between two years. Regarding cultivation conditions, Luthria et al. (2010) did not find differences in CGA content when comparing eggplant fruits grown in two farms, one using conventional growing conditions and the other using organic cultivation. However, Raigón et al. (2010) found that in eggplants grown in the same farm, organically produced eggplants had 30\% more total phenolic content than conventionally grown eggplants. An additional source of variation, 
in particular for comparing results from different research groups, comes from the methodology used for extraction and measurement of CGA (Luthria, 2012; Luthria and Mukhopadhyay, 2006).

All these data suggest that genetic, as well as many environmental factors (including extraction procedures), can affect the estimations of CGA content in eggplant and can contribute to differences observed among different works (Tab. 1). In particular, for an efficient breeding for CGA content it is important to include sufficient genetic diversity in the breeding programs as well as to reduce the nongenetic causes of variation and to standardize protocols for taking and processing samples.

\section{Breeding strategies for increased CGA content in eggplant}

Several strategies based on the exploitation of the naturally available variation can be applied for developing new cultivars of eggplant with increased chlorogenic content. A successful new commercial variety with improved concentrations of CGA will also require having good agronomic and commercial characteristics (i.e., good yield, lack of prickles, fruit shape and color adapted to consumer demands, etc.) (Daunay, 2008). Studies on variation for phenolic content, as well as new genomic information will be of great assistance for the development of these new improved cultivars.

The high intraspecific variation for CGA content and total phenolic content (Hanson et al., 2006; Mennella et al., 2012; Okmen et al., 2009; Prohens et al., 2007; Raigón et al., 2008; Stommel and Whitaker, 2003; Whitaker and Stommel, 2003) can be used in several ways in conventional breeding programs. For example, selection among the accessions or varieties with highest CGA content can result in the identification of materials with higher content in CGA. However, very likely, landraces with high content in CGA will not present agronomic and commercial characteristics competitive with present modern varieties, and its practical utility as commercial varieties may be limited. An alternative is the development of hybrids between accessions or lines with high content in CGA and complementary for agronomic traits. Eggplant hybrids are known to be heterotic for yield (Rodriguez-Burrruezo $e t$ al., 2008) and competitive with commercial hybrids in open field conditions (Muñoz-Falcón et al., 2008). Prohens et al. (2007) and Raigón et al. (2008) studied the total phenolic content in eggplant landraces and hybrids among them. Some of these hybrids, in particular those involving one or both parents with high content in phenolics, had values close to those of the parent with the highest value. Also, these hybrids can be used, through several breeding methods (Acquaah, 2012), to select and develop inbred lines with higher content in CGA and improved agronomic and commercial characteristics or to introgress this trait in élite lines.
Cultivated eggplant can be hybridized, although with different degrees of success, with a group of related species, including wild species and the cultivated scarlet $(S$. aethiopicum L.) and gboma (S. macrocarpon L.) eggplants (Daunay, 2008). Some of these species have high contents in CGA, which could be introgressed into eggplant. For example, $S$. incanum presents high contents in CGA (Ma et al., 2011; Prohens et al., 2013; Stommel and Whitaker, 2003). Solanum incanum is considered as the putative ancestor of eggplant (Lester and Hasan, 1990) and interspecific hybrids and subsequent backcross generations to eggplant are fully fertile (Prohens et al., 2013). The latter authors studied an interspecific family between $S$. melongena and $S$. incanum and found that even in the first backcross generation it was possible to select individuals with high content in CGA. This study also revealed that additive genetic effects were the most important in explaining CGA variation, suggesting that alleles from $S$. incanum should be placed in homozygous state to obtain a higher expression of the trait. Other species, like $S$. sodomaeum L. (=S. linneanum Hepper \& Jaeger) also show a higher CGA content than that of $S$. melongena (Mennella et al., 2010). However, eggplant lines with introgressions from S. sodomaeum did not present particularly high levels of CGA, very likely because these lines had not been selected for high CGA content (Mennella et al., 2010).

Molecular breeding strategies can also be of great utility for developing eggplant cultivars with improved CGA content. The availability of genetic maps (Barchi et al., 2010; Doganlar et al., 2002; Fukuoka et al., 2012; Wu et al., 2009) can be useful for the detection of quantitative trait loci (QTLs) affecting CGA content, as has been done for other traits like anthocyanin content or parthenocarpy (Barchi et al., 2012; Miyatake et al., 2012). Also, the CGA synthesis pathway in Solanaceae (Fig. 2) is known (Clé et al., 2008; Niggeweg et al., 2004) and the sequences of the six genes codifying for the enzymes involved in this pathway (phenylalanine ammonia lyase, PAL; cinnamate 4-hydroxilase, $\mathrm{C} 4 \mathrm{H}$; 4-hydroxycinnamoyl-CoA ligase, 4CL; hydroxycinnamoyl-coA shilimate/quinate hydroxycinnamoil transferase, HCT; $p$-coumaroyl ester 3'-hydroxilase, C3' $\mathrm{H}$; and, hydroxycinnamoyl CoA quinate hydroxycinnamoyl transferase, HQT) are available (Comino et al., 2007, 2009; Joët et al., 2010; Mahesh et al., 2007; Menin et al., 2010; Niggeweg et al., 2004). In consequence, it is possible to map these genes and to study their co-segregation with QTLs for CGA content. Sequencing of these alleles in a collection of germplasm, as well as TILLING or EcoTILLING strategies, can be useful to identify allelic variants for these genes (Pérezde-Castro et al., 2012). A selection of the most favorable alleles for each of these, which could be pyramided in a single variety (Ishii and Yonezawa, 2007), could be done through analyses of gene expression, as has been done on coffee (Lepelley et al., 2007). 


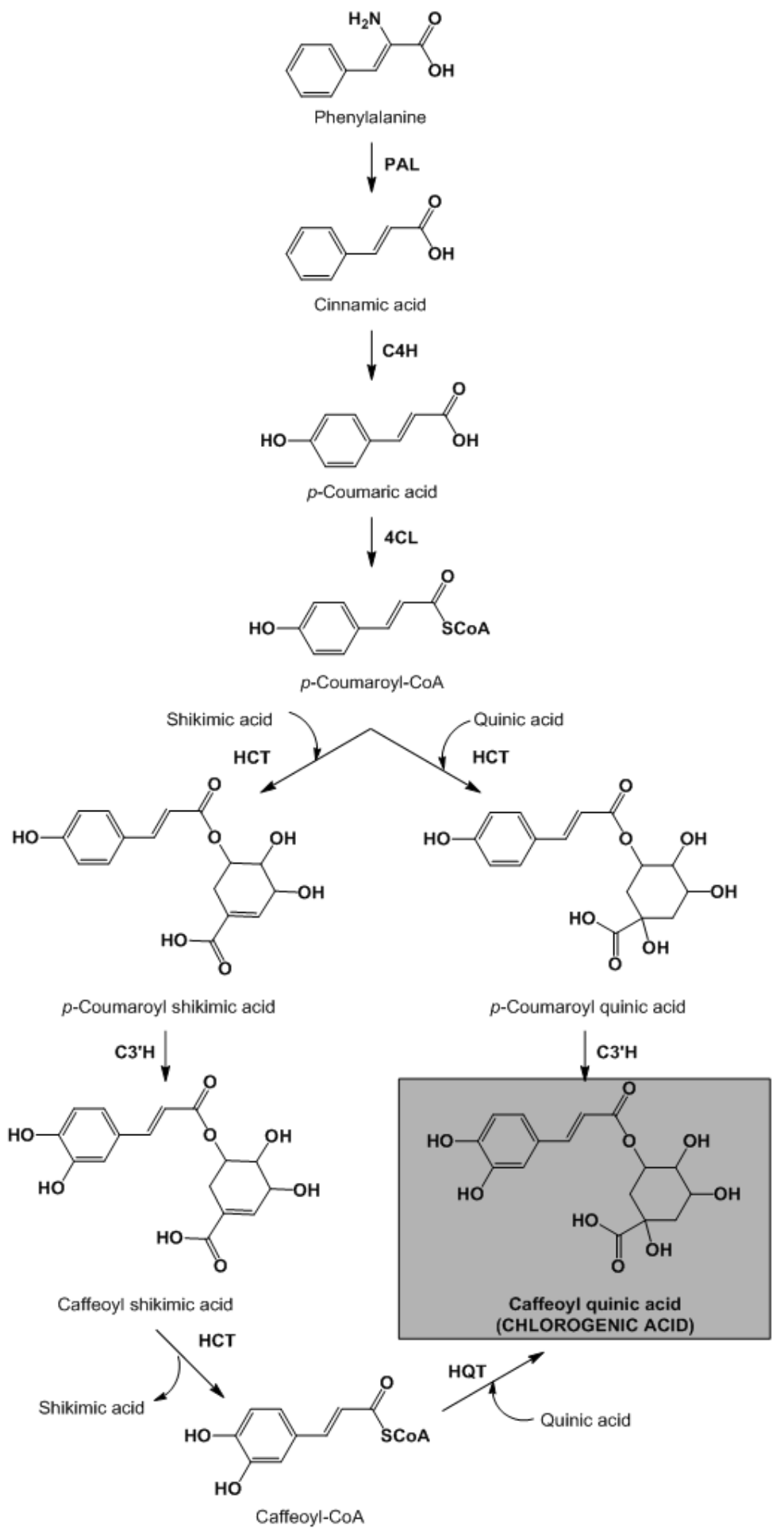

Fig. 2. Biochemical pathway for the synthesis of chlorogenic acid in eggplant (Clé et al., 2008; Comino et al., 2007, 2009; Joët et al., 2010; Mahesh et al., 2007; Menin et al., 2010; Niggeweg et al., 2004). Enzymes involved in the pathway are indicated: PAL, phenylalanine ammonia lyase; $\mathrm{C} 4 \mathrm{H}$, cinnamate 4-hydroxilase; 4CL, 4-hydroxycinnamoyl-CoA ligase; HCT, hydroxycinnamoyl-coA shilimate/quinate hydroxycinnamoil transferase; $\mathrm{C} 3$ ' $\mathrm{H}$, $p$-coumaroyl ester 3'-hydroxilase; HQT, hydroxycinnamoyl CoA quinate hydroxycinnamoyl transferase

Genetic transformation has been successfully applied for several traits in eggplant (Acciarri et al., 2000; Donzella et al., 2000; Pal et al., 2009). Niggeweg et al.
(2004) obtained transgenic plants of tomato overexpressing the HQT enzyme, which resulted in accumulation of higher levels of CGA. This opens the way to use similar 
approaches in eggplant. However, many sectors from the society, especially in Europe, reject genetically modified (GM) plants and regulations for getting approval of GM cultivars are long, complicated, and expensive (Raybould and Poppy, 2012).

\section{Fruit flesh browning as a side effect of CGA content improvement}

As in other fruits and vegetables, like apple or artichoke, oxidation of phenolic compounds, including CGA, present in the eggplant flesh results in flesh browning, which reduces apparent quality (Adams and Brown, 2007; Macheix, 1990; Mishra et al., 2012). When an eggplant fruit is cut open, the breakdown of the cellular compartments allows the orthophenolic compounds (hydroxycinnamic acid derivatives, like CGA) to be accessible to polyphenol oxidases (PPO), which catalyze their oxidation to quinones. Quinones then react non-enzymatically with $\mathrm{O}_{2}$ and other molecules to produce compounds which cause the browning of the flesh in the cut area (Mishra et al., 2012; Ramírez, 2002). Fujita and Tono (1988) found that CGA was the substrate for which eggplant PPO presented a greater affinity. However, Mishra et al. (2012) describe an intermediate specificity of eggplant PPO for CGA, showing only a $31 \%$ relative activity (using with 4-methylcatechol as $100 \%$ reference). In fact, eggplant PPO had a higher affinity for dihydrocaffeic acid or pyrocatachol, but a lower affinity for pyrogallol or gallic acid, than for CGA (Mishra et al., 2012). In any case, under the same conditions, the higher the content in CGA in the fruit flesh, the higher the browning.

The fact that differences in PPO activity exist among eggplant cultivars (Dogan et al., 2002; Mennella et al., 2012) suggests that selection for low PPO activity could be carried out. In this way, simultaneous selection for low PPO activity and high content in CGA content could result in materials with greater functional quality and low browning. Also, other factors, like intracellular $\mathrm{pH}$ or ascorbic acid content, which affect the PPO activity (Concellón et al., 2012; Doğan et al., 2002; Mishra et al., 2012), could play a role in the reduction of the degree of browning.

Prohens et al. (2007) studied the relationship between fruit flesh browning and the total phenolic content in eggplant. These authors found a wide variation for fruit browning among the cultivated germplasm, and a positive, but moderate, relationship between total phenolics content and fruit flesh browning $(\mathrm{r}=0.389)$, which indicates that it is possible to select varieties with high content in phenolics and low or moderate fruit flesh browning. More recently, the relationship between fruit flesh browning and total content in hydroxycinnamic conjugates (of which CGA was, by far, the most abundant) has been studied in an interspecific family between $S$. melongena and $S$. incanum (Prohens et al., 2013). In this study it has been found that the correlation coefficient was low $(\mathrm{r}=0.245$ for $\mathrm{F} 2$ and $\mathrm{r}=0.116$ for the first backcross to $S$. melongena).

The fact that PPO genes in eggplant display considerable variation and that seem to be situated in a cluster in chromosome 8 (Shetty et al., 2011) suggests that it is possible to use marker assisted selection for low PPO activity. Therefore, the data suggest that it is possible to select eggplant varieties with high content in CGA and low fruit flesh browning.

\section{Conclusions}

Given the many beneficial properties of CGA for human health and the high contents of this phenolic compound present in the eggplant fruit, developing new eggplant cultivars with improved functional quality resulting from increased CGA contents is of interest. The high genetic diversity among eggplant cultivars will facilitate the selection of sources of variation for high CGA content for breeding programs. Also, the use of wild relatives like $S$. incanum can result in the introgression of genes for high CGA values from these species. In both cases, the use of molecular breeding techniques, including marker assisted selection and the identification of allelic variants, can make an effective contribution to reaching this goal. Also, the low or moderate relationship between CGA content and fruit flesh browning together with selection for low PPO activity suggests that, in eggplant, it is possible to develop new cultivars with a combination of high CGA content and low fruit flesh browning.

\section{Acknowledgements}

Authors are grateful to Ministerio de Economía y Competitividad (AGL2009-07257 and AGL2012-34213), Universitat Politècnica de València (Proyectos de Nuevas Líneas de Investigación Interdisciplinares and Primeros Proyectos de Investigación), and VLC/Campus (Actividades Preparatorias de Proyectos Coordinados UPV-Fundación Hospital $\mathrm{La} \mathrm{Fe}$ ), for funding this research.

\section{References}

Acciarri N, Vitelli G, Arpaia S, Mennella G, Sunseri F, Rotino GL (2000). Transgenic resistance to the Colorado potato beetle in Bt-expressing eggplant fields. HortScience 35:722725.

Acquaah G (2012). Principles of plant genetics and breeding, 2nd Ed. Wiley-Blackwell, Oxford, UK, 758 p.

Adams JB, Brown HM (2007). Discoloration in raw and processed fruits and vegetables. Crit Rev Food Sci Nutr 47:319333.

Ahn EH, Kim DW, Shin MJ, Kwon SW, Kim YN, Kim DS, Lim SS, Kim J, Park J, Eum WS, Hwang HS, Choi SY (2011). Chlorogenic acid improves neuroprotective effect of PEP-1ribosomal protein S3 against ischemic insult. Exp Neurobiol 
32

$$
\text { 20:169-175. }
$$

Akanitapichat P, Phraibung K, Nuchklang K, Prompitakkul S (2010). Antioxidant and hepatoprotective activities of five eggplant varieties. Food Chem Toxicol 48:3017-3021.

Almeida AA, Farah A, Silva DA, Nunan EA, Gloria MB (2006). Antibacterial activity of coffee extracts and selected coffee chemical compounds against enterobacteria. J Agric Food Chem 54:8738-8743.

Andreotti C, Ravaglia D, Ragaini A, Costa G (2008). Phenolic compounds in peach (Prunus persica) cultivars at harvest and during fruit maturation. Ann Appl Biol 153:11-23.

Andújar I, Recio MC, Giner RM, Ríos JL (2012). Cocoa polyphenols and their potential benefits for human health. Oxid Med Cell Longev 2012:906252.

Arivalagan M, Gangopadhyay KK, Kumar G, Bhardwaj R, Prasad TV, Sarkar SK, Roy A (2012). Variability in mineral composition of Indian eggplant (Solanum melongena L.) genotypes. J Food Comp Anal 26:173-176.

Aubert S, Daunay MC, Pochard E (1989). Saponosides stéroïdiques de l'aubergine (Solanum melongena L.) I. Intérêt alimentaire, méthodologie d'analyse, localisation dans le fruit. Agronomie 9:641-651.

Azuma K, Ippoushi K, Nakayama M, Ito H, Higashio H, Terao $\mathrm{J}$ (2000). Absorption of chlorogenic acid and caffeic acid in rats after oral administration. J Agric Food Chem 48:54965500.

Barchi L, Lanteri S, Portis E, Stàgel A, Valé G, Toppino L, Rotino GL (2010). Segregation distortion and linkage analysis in eggplant (Solanum melongena L.). Genome 53:805-815.

Barchi L, Lanteri S, Portis E, Valé G, Volante A, Pulcini L, Ciriaci T, Acciarri N, Barbierato V, Toppino L, Rotino GL (2012). A RAD tag derived marker based eggplant linkage map and the location of QTLs determining anthocyanin pigmentation. PLOS ONE 7:e43740.

Burgos-Morón E, Calderón-Montaño JM, Orta ML, Pastor N, Pérez-Guerrero C, Austin C, Mateos S, López-Lázaro M (2012). The coffee constituent chlorogenic acid induces cellular DNA damage and formation of topoisomerase I- and II-DNA complexes in cells. J Agric Food Chem 60:73847391.

Cao GH, Sofic E, Prior RL (1996). Antioxidant capacity of tea and common vegetables. J Agric Food Chem 44:34263431.

Clé C, Hill LM, Niggeweg R, Martin CR, Guisez Y, Prinsen E, Jansen MA (2008). Modulation of chlorogenic acid biosynthesis in Solanum lycopersicum; consequences for phenolic accumulation and UV-tolerance. Phytochemistry 69:2149. 2156.

Clifford MN (2000). Chlorogenic acids and other cinnamates nature, occurrence, dietary burden, absorption and metabolism. J Sci Food Agric 80:1033-1043.

Coman C, Rugină OD, Socaciu C (2012). Plants and natural compounds with antidiabetic action. Not Bot Horti Agrobo
$40(1): 314-325$.

Comino C, Lanteri S, Portis E, Acquadro A, Romani A, Hehn A, Larbat R, Bourgaud F (2007). Isolation and functional characterization of a cDNA coding a hydroxycinnamoyltransferase involved in phenylpropanoid biosynthesis in $C y$ nara cardunculus L. BMC Plant Biol 7:14.

Comino C, Hehn A, Moglia A, Menin B, Bourgaud F, Lanteri S, Portis E (2009). The isolation and mapping of a novel hydroxycinnamoyltransferase in the globe artichoke chlorogenic acid pathway. BMC Plant Biol 9:30.

Concellón A, Zaro MJ, Chaves AR, Vicente AR (2012). Changes in quality and phenolic antioxidants in dark purple American eggplant (Solanum melongena L. cv. 'Lucia') as affected by storage at $0^{\circ} \mathrm{C}$ and $10^{\circ} \mathrm{C}$. Postharvest Biol Technol 66:35-41.

Chen ZY, Peng C, Jiao R, Wong YM, Yang N, Huang Y (2009). Anti-hypertensive nutraceuticals and functional foods. J Agric Food Chem 57:4485-4499.

Cho AS, Jeon SM, Kim MJ, Yeo J, Seo KI, Choi MS, Lee MK (2010). Chlorogenic acid exhibits anti-obesity property and improves lipid metabolism in high-fat diet-induced-obese mice. Food Chem Toxicol 48:937-943.

Das S, Raychaudhuri U, Falchi M, Bertelli A, Braga PC, Das DK (2011). Cardioprotective properties of raw and cooked eggplant (Solanum melongena L). Food Funct 2:395-399.

Daunay MC (2008). Eggplant, p. 163-220. In: Jaime Prohens FN (Ed.). Handbook of crop breeding, Vegetables II: Fabaceae, Liliaceae, Umbelliferae, and Solanaceae. Springer, New York, NY, USA.

Deußer H, Guignard C, Hoffmann L, Evers D (2012). Polyphenol and glycoalkaloid contents in potato cultivars grown in Luxembourg. Food Chem 135:2814-2824.

Doğan M, Arslan O, Doğan S (2002). Substrate specificity, heat inactivation and inhibition of polyphenol oxidase from different aubergine cultivars. International J Food Sci Technol 37:415-423.

Doganlar S, Frary A, Daunay MC, Lester RN, Tanksley SD (2002). A comparative genetic linkage map of eggplant (Solanum melongena) and its implications for genome evolution in the solanaceae. Genetics 161:1697-1711.

Donzella G, Spena A, Rotino G (2000). Transgenic parthenocarpic eggplants: superior germplasm for increased winter production. Mol Breed 6:79-86.

dos Santos MD, Almeida MC, Lopes NP, de Souza GE (2006). Evaluation of the anti-inflammatory, analgesic and antipyretic activities of the natural polyphenol chlorogenic acid. Biol Pharm Bull 29:2236-2240.

Fujita S, Tono T (1988). Purification and some properties of polyphenoloxidase in eggplant (Solanum melongena). J Sci Food Agric 46:115-123.

Fukuoka H, Miyatake K, Nunome T, Negoro S, Shirasawa K, Isobe S, Asamizu E, Yamaguchi H, Ohyama A (2012). Development of gene-based markers and construction of an in- 
tegrated linkage map in eggplant by using Solanum orthologous (SOL) gene sets. Theor Appl Genet 125:47-56.

Gajewski M, Katarzyna K, Bajer M (2009). The influence of postharvest storage on quality characteristics of fruit of eggplant cultivars. Not Bot Horti Agrobo 37(2):200-205.

Hallmann E (2012). The influence of organic and conventional cultivation systems on the nutritional value and content of bioactive compounds in selected tomato types. J Sci Food Agric 92:2840-2848.

Hallmann E, Rembiałkowska E (2012). Characterisation of antioxidant compounds in sweet bell pepper (Capsicum annuum L.) under organic and conventional growing systems. J Sci Food Agric 92:2409-2415.

Hanson PM, Yang RY, Tsou SCS, Ledesma D, Engle L, Lee TC (2006). Diversity in eggplant (Solanum melongena) for superoxide scavenging activity, total phenolics, and ascorbic acid. J Food Comp Anal 19:594-600.

Heck CI, Schmalko M, González de Mejía E (2008). Effect of growing and drying conditions on the phenolic composition of mate teas (Ilex paraguariensis). J Agric Food Chem 56:8394-8403.

Hurtado M, Vilanova S, Plazas M, Gramazio P, Fonseka HH, Fonseka R, Prohens J (2012). Diversity and relationships of eggplants from three geographically distant secondary centers of diversity. PLOS ONE 7:e41748.

Ishii T, Yonezawa K (2007). Optimization of the marker-based procedures for pyramiding genes from multiple donor lines: I. schedule of crossing between the donor lines. Crop Sci 47:537-546.

Jin XH, Ohgami K, Shiratori K, Suzuki Y, Koyama Y, Yoshida K, Ilieva I, Tanaka T, Onoe K, Ohno S (2006). Effects of blue honeysuckle (Lonicera caerulea L.) extract on lipopolysaccharide-induced inflammation in vitro and in vivo. Exp Eye Res 82:860-867.

Joët T, Salmona J, Laffargue A, Descroix F, Dussert S (2010). Use of the growing environment as a source of variation to identify the quantitative trait transcripts and modules of coexpressed genes that determine chlorogenic acid accumulation. Plant Cell Environ 33:1220-1233.

Khallouki F, Haubner R, Erben G, Ulrich CM, Owen RW (2012). Phytochemical composition and antioxidant capcity of various botanical parts of the fruits of Prunus $\times$ domestica L. from the Lorraine region of Europe. Food Chem 133:697-706.

Korkina LG (2007). Phenylpropanoids as naturally occurring antioxidants: from plant defense to human health. Cell Mol Biol 53:15-25.

Kwon YI, Apostolidis E, Shetty K (2008). In vitro studies of eggplant (Solanum melongena) phenolics as inhibitors of key enzymes relevant for type 2 diabetes and hypertension. Bioresour Technol 99:2981-2988.

Leiss KA, Maltese F, Choi YH, Verpoorte R, Klinkhamer PG (2009). Identification of chlorogenic acid as a resistance fac- tor for thrips in chrysanthemum. Plant Physiol 150:15671575.

Lepelley M, Cheminade G, Tremillon N, Simkin A, Caillet V, McCarthy J (2007). Chlorogenic acid synthesis in coffee: An analysis of CGA content and real-time RT-PCR expression of HCT, HQT, C3H1, and CCoAOMT1 genes during grain development in C. canephora. Plant Sci 172:978-996.

Lester RN, Hasan SMZ (1990). The distinction between Solanum incanum L and Solanum insanum L (Solanaceae). Taxon 39:521-523.

Lo Scalzo R, Fibiani M, Mennella G, Rotino GL, Dal Sasso M, Culici M, Spallino A, Braga PC (2010). Thermal treatment of eggplant (Solanum melongena L.) increases the antioxidant content and the inhibitory effect on human neutrophil burst. J Agric Food Chem 58:3371-3379.

Luthria D, Singh AP, Wilson T, Vorsa N, Banuelos GS, Vinyard BT (2010). Influence of conventional and organic agricultural practices on the phenolic content in eggplant pulp: Plant-to-plant variation. Food Chem 121:406-411.

Luthria DL, Mukhopadhyay S (2006). Influence of sample preparation on assay of phenolic acids from eggplant. J Agric Food Chem 54:41-47.

Luthria DL (2012). A simplified UV spectral scan method for the estimation of phenolic acids and antioxidant capacity in eggplant pulp extracts. J Funct Foods 4:238-242.

Lutz M, Henríquez C, Escobar M (2011). Chemical composition and antioxidant properties of mature and baby artichokes (Cynara scolymus L.), raw and cooked. J Food Comp Anal 24:49-54.

Ma C, Dastmalchi K, Whitaker BD, Kennelly EJ (2011). Two new antioxidant malonated caffeoylquinic acid isomers in fruits of wild eggplant relatives. J Agric Food Chem 59:9645-9651.

Macheix JJ, Fleuriet A, Billot J (1990). Fruit phenolics, Ed. CRC Press, Boca Ratón, FL, USA.

Mahesh V, Million-Rousseau R, Ullmann P, Chabrillange N, Bustamante J, Mondolot L, Morant M, Noirot M, Hamon S, de Kochko A, Werck-Reichhart D, Campa C (2007). Functional characterization of two p-coumaroyl ester 3'-hydroxylase genes from coffee tree: evidence of a candidate for chlorogenic acid biosynthesis. Plant Mol Biol 64:145-159.

Madrau MA, Piscopo A, Sanguinetti AM, Del Caro A, Poiana M, Romeo FV, Piga A (2009). Effect of drying temperature on polyphenolic content and antioxidant activity of apricots. Eur Food Res Technol 228:441-448.

Menin B, Comino C, Moglia A, Dolzhenko Y, Portis E, Lanteri $S$ (2010). Identification and mapping of genes related to caffeoylquinic acid synthesis in Cynara cardunculus L. Plant Sci 179:338-347.

Mennella G, Rotino GL, Fibiani M, D’Alessandro A, Francese G, Toppino L, Cavallanti F, Acciarri N, Lo Scalzo R (2010). Characterization of health-related compounds in eggplant (Solanum melongena L.) lines derived from introgression of 
34 allied species. J Agric Food Chem 58:7597-7603.

Mennella G, Lo Scalzo R, Fibiani M, D’Alessandro A, Francese G, Toppino L, Acciarri N, de Almeida AE, Rotino GL (2012). Chemical and bioactive quality traits during fruit ripening in eggplant (S. melongena L.) and allied species. J Agric Food Chem 60:11821-11831.

Mishra BB, Gautam S, Sharma A (2012). Browning of fresh-cut eggplant: Impact of cutting and storage. Postharvest Biol Technol 67:44-51.

Miyatake K, Saito T, Negoro S, Yamaguchi H, Nunome T, Ohyama A, Fukuoka H (2012). Development of selective markers linked to a major QTL for parthenocarpy in eggplant (Solanum melongena L.). Theor Appl Genet 124:1403-1413.

Monteiro MC, Farah A (2012). Chlorogenic acids in Brazilian Coffea arabica cultivars from various consecutive years. Food Chem 134:611-614.

Morishita H, Ohnishi M (2001). Absorption, metabolism and biological activities of chlorogenic acids and related compounds. Stud Nat Prod Chem 25:919-953.

Muñoz-Falcón JE, Prohens J, Rodríguez-Burruezo A, Nuez F (2008). Potential of local varieties and their hybrids for the improvement of eggplant production in the open field and greenhouse cultivation. J Food Agric Environ 6:83-88.

Nagel CW, Herrick IW, Graber WR (1987). Is chlorogenic acid bitter? J Food Sci 52:213-213.

Ngadze E, Icishahayo D, Coutinho TA, van der Waals JE (2012). Role of polyphenol oxidase, peroxidase, phenylalanine ammonia lyase, chlorogenic acid, and total soluble phenols in resistance of potatoes to soft rot. Plant Dis 96:186-192.

Niggeweg R, Michael AJ, Martin C (2004). Engineering plants with increased levels of the antioxidant chlorogenic acid. Nat Biotechnol 22:746-754.

Okmen B, Sigva HO, Mutlu S, Doganlar S, Yemenicioglu A, Frary A (2009). Total antioxidant activity and total phenolic contents in different Turkish eggplant (Solanum melongena L.) cultivars. Intl J Food Properties 12:616-624.

Olthof MR, Hollman PCH, Katan MB (2001). Chlorogenic acid and caffeic acid are absorbed in humans. J Nutrit 131:66-71.

Ong KW, Hsu A, Tan BK (2012). Chlorogenic acid stimulates glucose transport in skeletal muscle via AMPK activation: a contributor to the beneficial effects of coffee on diabetes. PLOS ONE 7:e32718.

Pal JK, Singh M, Rai M, Satpathy S, Singh DV, Kumar S (2009). Development and bioassay of Cry1Ac-transgenic eggplant (Solanum melongena L.) resistant to shoot and fruit borer. J Hort Sci Biotechnol 84:434-438.

Pérez-de-Castro AM, Vilanova S, Cañizares J, Pascual L, Blanca JM, Díez MJ, Prohens J, Picó B (2012). Application of genomic tools in plant breeding. Curr Genomics 13:179-195.

Prohens J, Blanca JM, Nuez F (2005). Morphological and molecular variation in a collection of eggplants from a secondary center of diversity: Implications for conservation and breeding. J Amer Soc Hort Sci 130:54-63.

Prohens J, Rodríguez-Burruezo A, Raigón MD, Nuez F (2007). Total phenolic concentration and browning susceptibility in a collection of different varietal types and hybrids of eggplant: Implications for breeding for higher nutritional quality and reduced browning. J Amer Soc Hort Sci 132:638646.

Prohens J, Whitaker BD, Plazas M, Vilanova S, Hurtado M, Blasco M, Gramazio P, Stommel JR (2013). Genetic diversity in morphological characters and phenolic acids content resulting from an interspecific cross between eggplant, $\mathrm{So}$ lanum melongena, and its wild ancestor (S. incanum). Ann Appl Biol 162:242-257.

Raigón MD, Prohens J, Muñoz-Falcón JE, Nuez F (2008). Comparison of eggplant landraces and commercial varieties for fruit content of phenolics, minerals, dry matter and protein. J Food Comp Anal 21:370-376.

Raigón MD, Rodriguez-Burruezo A, Prohens J (2010). Effects of organic and conventional cultivation methods on composition of eggplant fruits. J Agric Food Chem 58:6833-6840.

Ramírez EC, Virador VM (2002). Polyphenol oxidase, 509523 p. In: Whitaker JR, Voragen AGJ, Wong DWS (Eds.). Handbook of food enzymology. Marcel Dekker, New York, NY, USA.

Raybould A, Poppy GM (2012). Commercializing genetically modified crops under EU regulations: objectives and barriers. GM Crops Food 3:9-20.

Rodríguez-Burrruezo A, Prohens J, Nuez F (2008). Performance of hybrids between local varieties of eggplant (Solanum melongena) and its relation to the mean of parents and to morphological and genetic distances among parents. Eur J Hort Sci 73:76-83.

Sánchez-Mata MC, Yokoyama WE, Hong YJ, Prohens J (2010). Alpha-solasonine and alpha-solamargine contents of gboma (Solanum macrocarpon L.) and scarlet (Solanum aethiopicum L.) eggplants. J Agric Food Chem 58:5502-5508.

Sato Y, Itagaki S, Kurokawa T, Ogura J, Kobayashi M, Hirano T, Sugawara M, Iseki $\mathrm{K}$ (2011). In vitro and in vivo antioxidant properties of chlorogenic acid and caffeic acid. Int J Pharm 403:136-138.

Serra AT, Duarte RO, Bronze MR, Duarte CMM (2011). Identification of bioactive response in traditional cherries from Portugal. Food Chem 125:318-325.

Shetty SM, Chandrashekar A, Venkatesh YP (2011). Eggplant polyphenol oxidase multigene family: cloning, phylogeny, expression analyses and immunolocalization in response to wounding. Phytochemistry 72:2275-2287.

Sheu MJ, Chou PY, Cheng HC, Wu CH, Huang GJ, Wang BS, Chen JS, Chien YC, Huang MH (2009). Analgesic and anti-inflammatory activities of a water extract of Trachelospermum jasminoides (Apocynaceae). J Ethnopharmacol 126:332-338

Singh AP, Luthria D, Wilson T, Vorsa N, Singh V, Banuelos GS, 
Pasakdee S (2009). Polyphenols content and antioxidant capacity of eggplant pulp. Food Chem 114:955-961.

Stommel JR, Whitaker BD (2003). Phenolic acid content and composition of eggplant fruit in a germplasm core subset. J Amer Soc Hort Sci 128:704-710.

Sun T, Simon PW, Tanumihardjo SA (2009). Antioxidant phytochemicals and antioxidant capacity of biofortified carrots (Daucus carota L.) of various colors. J Agric Food Chem 57:4142-4147.

Suzuki A, Kagawa D, Ochiai R, Tokimitsu I, Saito I (2002). Green coffee bean extract and its metabolites have a hypotensive effect in spontaneously hypertensive rats. Hypertens Res 25:99-107.

Suzuki A, Yamamoto N, Jokura H, Yamamoto M, Fujii A, Tokimitsu I, Saito I (2006). Chlorogenic acid attenuates hypertension and improves endothelial function in spontaneously hypertensive rats. J Hypertens 24:1065-1073.

van der Sluis AA, Dekker M, de Jager A, Jongen WMF (2001). Activity and concentration of polyphenolic antioxidants in Apple: effect of cultivar, harvest year, and storage conditions. J Agric Food Chem 49:3606-3613.
Watanabe T, Arai Y, Mitsui Y, Kusaura T, Okawa W, Kajihara Y, Saito I (2006). The blood pressure-lowering effect and safety of chlorogenic acid from green coffee bean extract in essential hypertension. Clin Exp Hypertens 28:439-449.

Whitaker BD, Stommel JR (2003). Distribution of hydroxycinnamic acid conjugates in fruit of commercial eggplant (Solanum melongena L.) cultivars. J Agric Food Chem 51:34483454.

Wu F, Eannetta NT, Xu Y, Tanksley SD (2009). A detailed synteny map of the eggplant genome based on conserved ortholog set II (COSII) markers. Theor Appl Genet 118:927935.

Yang JS, Liu CW, Ma YS, Weng SW, Tang NY, Wu SH, Ji BC, Ma CY, Ko YC, Funayama S, Kuo CL (2012). Chlorogenic acid induces apoptotic cell death in U937 leukemia cells through caspase- and mitochondria-dependent pathways. In Vivo 26:971-978.

Zhao Y, Wang J, Ballevre O, Luo H, Zhang W (2012). Antihypertensive effects and mechanisms of chlorogenic acids. Hypertens Res 35:370-374. 